\title{
WHEN ANOINTING BECOMES ANNOYING: REMARKS ON THE POLISH SUPREME COURT'S JUDGMENT OF 20 SEPTEMBER 2013 (II CSK 1/13)
}

\author{
WOJCIECH BRZOZOWSKI*
}

\section{INTRODUCTION}

Freedom from religious pressure is commonly considered an inherent element of religious freedom. Interestingly, cases in which an individual becomes directly and involuntarily involved in religious practices are very rare. Over the last years, negative religious freedom has been discussed primarily in the context of the unwanted presence of religious content in the public sphere rather than involuntary participation in worship activities. In a democratic state ruled by law, such situations seem unlikely.

Considering the above, the judgment of 20 September 2013 (II CSK 1/13) handed down by the Polish Supreme Court (Sad Najwyższy) should warrant all the more attention. In this judgment, the Supreme Court ruled in a case that involved a Catholic priest administering the sacrament of anointing of the sick to a non-believer previously put in a drug-induced coma. This case raised much interest among Polish legal scholars but is not widely known abroad, despite the fact that it touches upon key aspects of protection of religious freedom.

\section{Circumstances of The Case}

In January 2009, the claimant was admitted to a cardiac surgery ward where he underwent pre-scheduled surgery. Immediately after the surgery, he regained consciousness but did not respond to attempts at communication. Soon thereafter he was put in a drug-induced coma and remained in that state until the end of his stay in the hospital. During this period an incident occurred that became the cause of action for the legal proceedings initiated by the claimant. A Catholic priest, in his capacity as hospital chaplain under a

DOI: $10.1515 /$ wrlae-2015-0036

*PhD, Assistant Professor, Faculty of Law and Administration, University of Warsaw, w.brzozowski@wpia.uw.edu.pl. 
contract signed with the hospital, administered the sacrament of anointing of the sick to the comatose claimant. The priest was unaware of the religious convictions of the patient; he assumed that the patient was most likely a Roman Catholic, basing this assumption on the religious structure of Polish society ${ }^{1}$. The priest also assessed the situation in the light of canon law, which enables the conferral of a sacrament upon an unconscious person ${ }^{2}$, whereas the sacrament so conferred upon a non-believer is invalid. In view of the patient's grievous situation (the risk of death), the priest decided that he should proceed with the anointing.

After some time the claimant regained consciousness and was released from the hospital. It was not until late May or early June 2009 when he learnt about having been administered a sacrament by a priest. This fact became known to him after he read his medical records, which contained a note about the administered sacrament. The claimant alleges that in the aftermath of learning about this he experienced a nervous breakdown and that his physical and mental state deteriorated. Although he has been baptised and never officially left the Catholic Church (has not performed the formal act of apostasy), the claimant describes himself as a non-believer. He did not want any sacraments to be conferred upon him under the Rites of the Catholic Church, but did not express the relevant negative wish upon his admission to the hospital.

\section{FINDINGS OF THE COURTS OF THE FIRST AND SECOND INSTANCE}

In view of the above circumstances, the claimant sought an award of PLN 90,000 (at the time approx. EUR 20,000) from the defendant (hospital) in moral damages resulting from an infringement of his personal interests. Generally speaking, personal interests (dobra osobiste) are defined as legally recognised intangible values closely related to a human being, including physical and psychological integrity ${ }^{3}$. Personal interests include the freedom

\footnotetext{
${ }^{1}$ According to the Central Statistical Office, in 2010 Roman Catholics made up over $96 \%$ of Poland's population; see Kościót Katolicki w Polsce 1991-2011. Rocznik statystyczny, [Catholic Church in Poland 1991-2011. Statistical yearbook] (Główny Urząd Statystyczny 2014) 14. However, the figure represents official religious membership and does not express the actual level of the population's religiousness. According to a study by the Institute of Statistics of the Catholic Church SAC (Instytut Statystyki Kościoła Katolickiego SAC), in 2009 the percentage of dominicantes (the faithful attending Sunday Mass) was $41.5 \%$, while the percentage of communicantes (the faithful receiving communion) was $16.7 \%$. The hospital where the incident happened is located in the territory of the Szczecin and Kamien Pomorski Diocese, which is home to one of the least religious local populations in Poland (in 2014 the Diocese recorded the dominicantes ratio of $24.9 \%$, as compared to the national average of $39.1 \%$ ); <http://www.iskk.pl/kosciolnaswiecie/211-praktyki-niedzielnepolakow-dominicantes.html> (accessed 21 March 2016). See also Marcin A. Mielczarek, 'Święta wolne od pracy a równouprawnienie związków wyznaniowych', [Non-working feast days and equality of religious organizations’ rights] (2014) 8 Państwo i Prawo 65-66.

${ }^{2}$ Pursuant to Can. $1004 \S 1$ : "The anointing of the sick can be administered to any member of the faithful who, having reached the use of reason, begins to be in danger of death by reason of illness or old age."

${ }^{3}$ For a discussion on the concept of personal interests see Maksymilian Pazdan, 'Artykuł 23' [Article 23] in Krzysztof Pietrzykowski (ed), Kodeks cywilny. Komentarz, t. I [Civil Code. Commentary, vol. I] (C.H. Beck 2015] 109-112.
} 
to profess (or not to profess) a religion and to engage (or not to engage) in religious practices ${ }^{4}$.

The provisions invoked as the legal basis of the claimant's suit read as follows:

"In the case of an infringement of one's personal interests, the court may award pecuniary compensation for moral loss suffered by a person whose personal interests have been infringed, or may, on this person's demand, adjudge a pecuniary award to be paid for a social purpose chosen by this person, irrespective of other means necessary to remedy the effects of the infringement [...]" (Article $448 \S 1$ of the Polish Civil Code, hereinafter referred to as "CC")

"The personal interests of a human being, in particular health, freedom, dignity, freedom of conscience, a surname or pseudonym, image, secrecy of correspondence, inviolability of home, and scientific, artistic, inventor's and rationalising activity, shall be protected by civil law independent of protection envisaged in other provisions" (Article $23 \mathrm{CC}$ )

"The person whose personal interests are threatened by another person's action may demand the cessation of the action unless the action is not unlawful. In the case of an infringement, the [noninfringing] person may demand that the person who committed the infringement perform acts necessary to remove effects of the infringement and in particular make an appropriate statement in an appropriate form. In accordance with the rules set out in the Civil Code, the claimant may also assert compensation for a moral loss or the payment of an appropriate sum of money to a designated social purpose" (Article $24 \S 1 \mathrm{CC}$ )

The above provisions should be interpreted also in the light of the Constitution of the Republic of Poland (hereinafter referred to as "the Constitution"), which guarantees freedom of conscience and religion to everyone. In particular, the Constitution holds as follows:

"Freedom of religion shall include [...] the right of individuals, wherever they may be, to benefit from religious services" (Article 53 para. 2 of the Constitution)

"No one shall be compelled to participate or not participate in religious practices" (Article 53 para. 6 of the Constitution)

"No one may be compelled by organs of public authority to disclose his life outlooks, religious convictions or belief" (Article 53 para. 7 of the Constitution)

In its defence, the hospital argued that the patient had failed to demonstrate that the reception of the sacrament of anointing of the sick had resulted in him having suffered any negative medical consequences. Since the patient is not a believer, the argument went, then religious rites performed upon him cannot be considered an actual sacrament and should be of no significance whatsoever for the claimant.

\footnotetext{
4 ibid. 114.
} 
The regional court which heard the case in the first instance did not share the claimant's arguments. The court held that the claim pursued by the claimant should not be given merit because the claimant failed to explain what kind of personal interest had been infringed by the actions of the defendant. In the court's view, the claimant also failed to show that the defendant's actions were unlawful and culpable. The court judged that since the priest's actions complied with canon law, they had been taken in accordance with the principles of social coexistence (zasady wspótzycia społecznego). Since the claimant had not performed the act of apostasy and was still formally a member of the Catholic Church, he was a subject of its internal laws. Furthermore, according to the regional court, an assessment of an infringement of personal interests should be based on objective criteria rather than the subjective experiences of the person alleging the infringement. The court held that the claimant's emotional response to the situation was "exaggerated".

The court of appeal that heard the case in the second instance presented a different assessment of the claimant's assertions. It rejected the argument that the absence of the claimant's disaffiliation from the Catholic Church should be considered a decisive factor in determining the lawfulness of the chaplain's actions. The prohibition on forcing people to participate or not participate in religious practices applies to everyone, irrespectively of whether a given person is or is not affiliated with a religious group. The court further argued that interpretation of the provisions of canon law was irrelevant to the case. However, it held that the assessment of whether personal interests have or have not been infringed in a given case may not be based on the declared personal feelings of the claimant, but must take into consideration the social and cultural context of the incident in question. According to the court of appeal, the priest's actions did not materially interfere with the patient's freedom of conscience. From the perspective of a non-believer, the acts performed by the priest should be perceived as completely neutral, the court argued; it added that anointment is a symbolic act with positive connotations and that, as an attempt to provide assistance to another person, may not be considered evidence of disrespect for this person, even if such assistance is undesired. The court emphasised that the anointment did not infringe the claimant's personal inviolability since the physical contact between the priest and the claimant was no more intense than the everyday random contacts a person has with others. As regards the priest's unawareness of the claimant's religious beliefs, such unawareness was, in the court's opinion, justified because the hospital has no right to ask patients about their attitudes to religion, including preferences as to anointment. The collection of such information is prohibited under Article 53 para. 7 of the Constitution (right to refrain from disclosing one's religious beliefs). The court also argued that the hospital chaplain was not obliged to inquire as to the patient's religious beliefs, given that at the initial stage of his stay in hospital there had been no basis for considering whether or not he should receive a sacrament. 


\section{ASSESSMENT OF THE SuPREMe COURT}

A complaint in cassation was filed against the judgment entered by the court of appeal, and the case was decided by the Supreme Court, which reversed the challenged judgment and remanded the case for reconsideration to the court of appeal. In doing so, the Supreme Court allowed the complaint in cassation and ruled in the complainant's (the original claimant's) favour.

The Supreme Court noted that the parties had not contested the following facts of the case regarding the claimant's stay in the hospital: the patient received the sacrament of anointing of the sick while in a drug-induced coma, and was unable to oppose it. It was contested, however, whether or not the hospital chaplain's actions led to an infringement of a personal interest (religious freedom) of the claimant. Commenting on this issue, the Supreme Court held that the acceptance of a sacrament is undoubtedly a religious practice, while conferring a sacrament on a person who does not wish to receive it is tantamount to subjecting this person to an involuntary religious practice. The Court argued that in the Catholic Church conferral of a sacrament is an act that directly affects the specific person who appears in the role of the recipient. If a non-believer is subjected to a religious practice (or a believer is subjected to a religious practice of a different denomination), this violates the religious freedom of the individual concerned. One cannot reasonably argue that a sacrament presents spiritual value only for the faithful, and has no consequences whatsoever for atheists or agnostics. The Supreme Court emphasised:

"For a believer, acceptance of a sacrament is a profound spiritual act. The activity through which this act is performed does not become trivial or irrelevant only because it is executed towards a nonbeliever who objects to it. In consequence, subjecting a person to unwanted religious practices is not a minor and trivial incident that does not warrant protection under Article 23 CC."

Next, the Supreme Court referred to the argument that the hospital could not inquire about the religious convictions of patients. The Court remarked that an organisation which provides health care services must have access to information about the personal philosophy or denomination of recipients of its services. The Constitution affords to everyone, including patients, the right "to benefit from religious services" (Article 53 para. 2 of the Constitution). This right is recognised both internationally and by national jurisdictions ${ }^{5}$. In Poland, the law gives patients the right to receive pastoral care, and - in the event a patient's health deteriorates or a threat to their life emerges - obliges a hospital to provide a patient access to a clergyman of the patient's denomination ${ }^{6}$. Quite obviously, this right cannot be exercised if one does not know whether a patient wants to receive such care at all or wishes to have access to a clergyman of their denomination. Last but not least, it would

\footnotetext{
5 See Norman Doe, Law and Religion in Europe: A Comparative Introduction (Oxford University Press 2011) 203-204.

${ }^{6}$ See Chapter 10 of the Patient's Rights and Commissioner for Patient's Rights Act of 6 November 2008 (uniform text in the Journal of Laws of 2012 item 159, as amended).
} 
be impossible to offer pastoral care without knowing what a patient's denomination is. It is unacceptable to apply any presumption as to a patient's affiliation with a dominant religion if the patient has not been asked about it or has declined to provide an answer to this question.

At this point the Supreme Court criticised the hospital for its lack of consistency: on the one hand, the hospital refrained from inquiring about the patient's religious beliefs invoking his constitutional right to remain silent on religious matters while, on the other, decided to place a certificate of the conferral of a sacrament in the patient's medical records.

It was noted in the Supreme Court's judgment that in certain situations the exercise of a patient's rights may be problematic. This may happen if the patient is admitted in a condition that prevents determination of their religious convictions or their wishes regarding pastoral care. Since the courts of the first and second instance did not have to deal with such a situation in the discussed case (the claimant's admission was scheduled and he was conscious before the surgery), the Supreme Court did not discuss this aspect any further.

\section{TWO PERSPECTIVES OF THE REVIEW}

The case heard by the Supreme Court deserves special attention, as it represents a clash of two perceptions of the role of religion in the public sphere and the autonomy of an individual in matters of faith. An unfortunate coincidence of circumstances has turned a deeply-rooted worldview dispute into a legal dispute.

From the secular perspective, religious freedom has clearly been violated. The case involves interference in the sphere of the patient's physical and psychological integrity. The violation of the patient's inviolability is admittedly a minor one, although it is hardly disputable that when the sacrament of anointing of the sick is administered, the priest initiates direct physical contact with the recipient of the sacrament, spreading holy oils on the recipient's body. A bigger problem is the psychological distress related to the fact that the patient has forcibly been entangled in the religious practices of an institution that he vehemently opposes and whose beliefs are alien to $\mathrm{him}^{7}$. The argument that the claimant was formally a member of the Catholic Church is of no significance: such a membership, most often resulting from parents' decision to have their child baptised, should not be interpreted as in blanco consent to all future actions taken by the Church vis-a-vis its "member", who may never have been involved in or manifested any affiliation with the life of the Church as a community ${ }^{8}$.

\footnotetext{
${ }^{7}$ One of the Polish authors failed to take note of this aspect in his argument that "the claimant has mistakenly evaluated the sacrament of anointment and felt disturbed by it; however, a fear arising out of ignorance provides no substantiation for the allegation that a personal interest has been infringed upon" - Zbigniew Strus, "Glosa do wyroku Sądu Najwyższego z dnia 20 września 2013 r. w sprawie II CSK 1/13', [Commentary to the judgment of the Supreme Court of 20 September 2013, case no. II CSK 1/13] (2013) 5 Forum Prawnicze 41. The remark of the claimant's ignorance seems to be superfluous and condescending.

${ }^{8}$ It is hard to share the view that a failure to perform pastoral ministry (i.e. not conferring the sacrament of anointing of the sick) would be an infringement of the priest's personal interests; Bartosz Rakoczy, 'Glosa do wyroku Sądu Najwyższego z dnia 20 września 2013 r. w sprawie
} 
From the perspective of an advocate of secularity, it is particularly outrageous that the priest assumed that he was dealing with a Catholic based on the fact that Catholics are the dominant religious group within Polish society. Such an assumption, whenever applied, significantly undermines respect for the rights of religious minorities because it presents Catholicism as "the default religion", and requires a greater degree of care in asserting their rights by those professing other religions or non-believers. The essence of religious freedom is enabling each and every individual to choose their own religious beliefs and respect for their choices. An argument based on statistics is irrelevant because it undermines the moral autonomy of individuals and conditions it on dominant attitudes in their environment. It is thus better not to administer a sacrament to a believer who has failed to make sure to receive it beforehand than to confer it on somebody against that somebody's wishes. The hospital's disrespectful approach to religious freedom and moral autonomy is also evidenced by the inclusion of information about the sacrament in medical records: this was done as if such information pertained to a health care service. Given all the circumstances, a non-believer could only reinforce their belief that they are a victim in the Catholic Church's struggle to expand its influence over the public sphere.

The matter takes on a different appearance from the religious perspective. Here, the most surprising element is the strictness of the secular position. A supporter of the presence of religion in the public sphere may admit that the case involved the conferral of a sacrament on a person who did not want it, but can hardly understand the reason for the patient's fierce protest. The sacrament of anointing is a non-invasive rite and does not involve inflicting pain on the recipient. In the discussed case, the person was in a coma and did not consciously take part in a religious practice; he was not even aware of having been subjected to such a practice until he found out about it by pure chance. Participation in such a practice is not socially perceived as a reason for ridicule or dishonour. The question can be posed whether the priest's action - aside from incidental physical contact related to the spreading of holy oils - had a greater potential of interfering with the moral autonomy of the patient than, for instance, a prayer for the health of a nonbeliever, which obviously cannot be forbidden even if a non-believer does not wish to the prayer to be said ${ }^{9}$.

The religious perspective reverses the columns of the "profit and loss account" of a sacrament administered to a person of a different (or nonexistent) religious affiliation. For a person not affiliated with any religious group, a sacrament is an act without any real significance, even though it is capable of triggering annoyance or displeasure in such a person. For a believer who has not expressed detailed instructions in the case of losing

II CSK 1/13' [Commentary to the judgment of the Supreme Court of 20 September 2013, case no. II CSK 1/13] (2016) 8 Przegląd Prawa Wyznaniowego 220. Respecting the constitutional religious freedom of a patient cannot be considered an unlawful act and the moral integrity of a priest is not a greater value than the moral integrity of a patient.

${ }^{9}$ See Justyna Krzywkowska, Aleksandra Bitowt, 'Poddanie człowieka nieakceptowalnym przez niego praktykom religijnym' [Submitting a person to unaccepted religious practices] in Piotr Stanisz et al. (eds) Aktualne problemy wolności myśli, sumienia i religii, [Current problems of freedom of thought, conscience and religion] (Wydawnictwo KUL 2015) 203. 
consciousness, the consequences of not receiving the sacrament of anointing are far more severe. A withdrawal of pastoral ministry may even deprive such a person of the blessings of eternal life. It is thus better to risk causing shortterm psychological discomfort in a person professing a different religion or a non-believer than to expose a believer to the threat of damnation in the name of strictly enforced religious freedom. This line of argument is supported by the fact that the patient was formally affiliated with the Catholic Church: even if he had not been involved in the life of this community for a long time, he was still a member of the Church. Furthermore, cases of conversions in the face of imminent death are not uncommon. From the religious perspective, the case heard by the Supreme Court is merely another example of the dispute of philosophies between non-tolerant secularism and the attitude of respect for the traditional role of Christianity in Europe.

\section{IS THERE A GOOD SOLUTION?}

The positions taken by the proponents and opponents of the presence of religion in the public sphere are so far apart that one may doubt if there is any common ground between them. The tone of some commentaries to the judgment is an indication of this divide ${ }^{10}$. Consequently, if the conflict is to be resolved by way of compromise, a resolution must be reached beyond the constraints of ideological dispute and must be based on objective criteria applied to a review of the situation. In other words, it is crucial that both sides are presented with a persuasive justification for such a resolution so that neither party believes their sensitivity and moral arguments have been disregarded.

As far as good faith and willingness to compromise are concerned, the attitude of the claimant is indeed controversial. As he learned about having been anointed he might have felt psychological discomfort, but the allegation that he was at risk of a heart attack seems to be an exaggeration. The compensation for moral loss sought by the claimant from the hospital seems to be excessive and out of touch with economic realities. The nature of the claim may suggest that the real purpose that guided the claimant's actions was not to obtain compensation for the sustained harm but to make money and fight a religion.

However, it is fair to say that also the hospital's conduct and line of defence are hardly justifiable. It is not a viable argument that since nonbelievers do not recognise the spiritual dimension of religious practices, they should remain indifferent in a situation that involves being subjected to such practices. Such a statement demonstrates an absence of respect for the feelings of atheists and agnostics. A similar tone is struck in the argument that the prevalence of Catholics within society provides justification for the

\footnotetext{
${ }^{10}$ The author of one of the commentaries expresses concern that allegations of infringement of personal interests can be asserted against people who spontaneously buried victims of the Second World War in graves marked with crosses since the former did not know the religious beliefs of the latter - Strus, Glosa (n 7) 42. It is difficult to determine how this example is relevant to the discussed case because it refers to facts from the past, and the people who might have been at risk of an infringement could not (and did not) pursue such allegations, for obvious reasons.
} 
performed acts: it suggests that religious minorities are nothing more than a statistical anomaly, and a negligible element of society's religious composition.

It is surprising and annoying (not only to non-believers) that the difference between secular law and Church law is not discerned. If a public hospital includes information on a conferred sacrament in a patient's medical records, this may be felt hilarious. However, if a state court, established to safeguard the religious freedom of individuals, examines and assesses whether a priest's actions comply with canon law, this is improper and alarming. Such an assessment can be made exclusively by ecclesiastical courts.

On the one hand, striking a fair balance in the discussed case requires admitting that it actually involved an infringement of the claimant's personal interests. On the other hand, it seems that given the priest's motives and the nature of the interference in the sphere of inviolability it would be sufficient to acknowledge that the claimant was right or, optionally, award him only token compensation for moral loss ${ }^{11}$.

The Supreme Court declared that it was not in a position to develop any systemic solution to the problem that would prevent similar violations from happening in the future. However, such constraints have not been imposed on those commenting on the judgment. Arguably, hospital admittance forms could contain a separate section with questions about pastoral ministry. Such questions should be phrased in strict accordance with the legal responsibilities of a hospital, and answers to them should be given on a voluntary basis. This section of the form, displayed on a separate sheet of paper, could be - at the patient's request - placed in a sealed envelope and read by hospital personnel only in the event that the patient is unable to express their wishes on their own. This rule, if applied in the case heard by the Supreme Court, could allow for the avoidance of a legal dispute as the patient was admitted on schedule, and was conscious and capable of answering questions about his religious beliefs.

Different problems altogether are posed by the hypothetical scenario of a person remaining unconscious (unable to express their will) from the very moment of admittance to hospital. In this case, finding a good solution is very difficult. The problem does not arise when a given person had left clear instructions regarding pastoral assistance at some point before losing consciousness. If this is not the case, it seems acceptable to infer such intention from signs of a person's religious affiliation, and especially religious symbols worn by the patient on the day of admittance. Credible declarations of the patient's loved ones can also be used as alternative indicators of religious affiliation. The above suggestions, albeit capable of resolving many problematic issues, are not sufficient in all circumstances. There is no answer to the question about what protocol should be followed in

\footnotetext{
${ }^{11}$ This was the direction of further developments in the case. According to media reports, the court of appeal to which the case was remanded ruled that personal interests had been violated but no compensable harm was shown; see $<$ http://szczecin.wyborcza.pl/szczecin/1,34959,15322189,Pacjent_namaszczony_wbrew_wl asnej_woli_nie_dostanie.html> (accessed 21 March 2016).
} 
situations where a patient's religious beliefs cannot be determined on the basis of external signs and family members are not easily contactable or provide conflicting statements in respect of the patient's creed. A solution that would require patients carrying cards with the relevant information is hardly practicable. while the creation of a central register of hospital pastoral care declarations, similar to that recording objections to organ donation, would not only be irrational but also possibly unlawful, as it would involve the stateorganised collection of personal religious data. This is because such data would be collected "in advance", and not in connection with a specific hospital admission.

If, however, the latter idea is entertained, a register of that kind should satisfy two conditions. First, it should be based on positive declarations, thus operate on an opt-in rather than opt-out basis. This means that declarations should express willingness to accept pastoral care, and not an objection to such care, similarly to declarations on the willingness to sign up for religious education classes at schools. Second, religious communities should play the central role in the collection and safekeeping of such declarations. This would be appropriate given the restrictions regarding the collection of data on citizens' denominations imposed on public authorities, but also from the perspective of religious groups' ability to persuade members to submit such declarations.

\section{CONCLUSIONS}

The judgment of the Supreme Court was based on Polish law. However, it hinges upon certain issues typical for the protection of religious freedom within the European legal space.

First, surprisingly often legal disputes, which are depicted in public debate as subsequent instances of the dispute of outlooks as to the role of religion, can actually be reduced to, and considered as, disputes over the correct design of procedures ${ }^{12}$. The existence of appropriate procedures for pastoral care in health care facilities would have eliminated the necessity of the Supreme Court stepping in to decide the case. Furthermore, this would have prevented a ritual clash between proponents and opponents of the secularity of public institutions from happening in a courtroom.

Second, the judgment is a reminder of the necessity for developing clear-cut and objective criteria that should be applied in assessing violations of negative religious freedom that do not involve any visible harm caused to a person who seeks legal aid and cites psychological distress. The European

\footnotetext{
12 This conclusion may be applied to the two cases in which the European Court of Human Rights held that Poland violated religious freedom (Article 9 of the European Convention on Human Rights). The case Grzelak v Poland (App no 7710/02, judgment of 15 June 2010) concerns the placement of a straight line against the subject "religion/ethics" on a school report, which effectively disclosed the fact that a student had not attended religious education classes. The violation identified in the other case, Jakóbski v Poland (App no 18429/06, judgment of 7 December 2010), involved a failure to place an inmate on an ordinary vegetarian diet, in accordance with the religious convictions of the inmate in question. Both cases could easily have been resolved without involving an international judicial body.
} 
Court of Human Rights is no stranger to this problem ${ }^{13}$. Even if monetary claims asserted in connection with such distress tend to be exorbitant, this does not mean that the emotional sphere of claimants should not be afforded protection. In certain situations, the problem may be solved by officially acknowledging that a claimant's claims have merit but without awarding any financial compensation.

\section{References}

Doe Norman, Law and Religion in Europe: A Comparative Introduction (Oxford University Press 2011).

Kościół Katolicki w Polsce 1991-2011. Rocznik statystyczny (Główny Urząd Statystyczny 2014).

Krzywkowska Justyna, Bitowt Aleksandra, 'Poddanie człowieka nieakceptowalnym przez niego praktykom religijnym' [Submitting a person to unaccepted religious practices] in Piotr Stanisz et al. (eds) Aktualne problemy wolności myśli, sumienia i religii, [Current problems of freedom of thought, conscience and religion] (Wydawnictwo KUL 2015).

Mielczarek Marcin A., 'Święta wolne od pracy a równouprawnienie związków wyznaniowych', [Non-working feast days and equality of religious organizations' rights] (2014) 8 Państwo i Prawo.

Pazdan Maksymilian, 'Artykuł 23' [Article 23] in Krzysztof Pietrzykowski (ed), Kodeks cywilny. Komentarz, t. I [Civil Code. Commentary, vol. I] (C.H. Beck 2015].

Rakoczy Bartosz , 'Glosa do wyroku Sądu Najwyższego z dnia 20 września $2013 \mathrm{r}$. w sprawie II CSK 1/13' [Commentary to the judgment of the Supreme Court of 20 September 2013, case no. II CSK 1/13] (2016) 8 Przegląd Prawa Wyznaniowego.

Strus Zbigniew, 'Glosa do wyroku Sądu Najwyższego z dnia 20 września 2013 r. W sprawie II CSK 1/13', [Commentary to the judgment of the Supreme Court of 20 September 2013, case no. II CSK 1/13] (2013) 5 Forum Prawnicze.

\footnotetext{
${ }^{13}$ An enlightening example of this is the much-publicized case Lautsi and Others $v$ Italy (App no 30814/06) in which the Grand Chamber ultimately refused to grant a remedy for the applicant (judgment of 18 March 2011), holding that her subjective perception is not sufficient for declaring a violation of Article 2 of Protocol 1 to the Convention. The Grand Chamber made its ruling despite Second Section's decision to accept the applicant's allegations without requesting any additional evidence in support of the same (judgment of 3 November 2009).
} 